\title{
The effect of relative humidity on tensile strength and water vapor permeability in chitosan, fish gelatin and transglutaminase edible films
}

\author{
Sofia ALVARADO ${ }^{1 *}$, Glória SANDOVAL ${ }^{1}$, Isidro PALOS², Simón TELLEZ², \\ Yaneli AGUIRRE-LOREDO ${ }^{3}$, Gonzalo VELAZQUEZ ${ }^{3}$
}

\begin{abstract}
Composite films of chitosan, fish gelatin and microbial transglutaminase (MTgase) were developed. Films were produced by the casting method and dried at room temperature for $30 \mathrm{~h}$, conditioned for 7 days at $30{ }^{\circ} \mathrm{C}$ at a relative humidity (RH) from 11 to $90 \%$, and characterized. Chitosan:fish gelatin films in different proportions (100:0, 75:25, 50:50) with MTgase, were subjected to tensile properties and water vapor transmission (WVT) testing. The results showed that tensile strength decreased with an increase in $\mathrm{RH}$ and with an increase in gelatin content. Percent of elongation also increased with increasing $\mathrm{RH}$ and gelatin concentration. Water vapor transmission showed an increase proportional to an increase in RH with the presence of gelatin being unfavorable for reducing WVT. Results in this work allowed studying the effect of relative humidity on tensile and water vapor properties of chitosan and fish gelatin films.
\end{abstract}

Keywords: biodegradable films; tensile and water vapor properties; enzymatic cross-linking.

Practical Application: Assessment of tensile and water vapor properties of biopolymeric films made from chitosan and gelatin.

\section{Introduction}

Plastic materials have diverse applications; however, they are one of the most important pollutants of soils and oceans mainly because of their difficult mineralization (Allsopp et al., 2007). Given the low percentage of reuse and biological recycling, plastics have an important environmental impact due to their short life cycle and high disposal volume (Stevens, 2002). As a result, in recent years, technological developments to modify synthetic polymers as well as develop new polymers that can be incorporated into the biological cycle when discarded have been encouraged (Rabell-Contreras et al., 2011).

Because of this situation, biopolymers have generated a great interest in the research and development of materials. Natural polymers or polymers derived from natural sources, such as proteins or polysaccharides, offer the best alternatives because of their biodegradability and compatibility with the environment (Krochta et al., 1994). Materials based on wheat and soy gluten (Yildirim \& Hettiarachchy, 1998), chitosan (Han et al., 2004; Villada et al., 2007), casein (Arvanitoyannis et al, 1998; Oh et al., 2004; Lacroix, 2009) zein (Ávila, 2011), among others, are used to prepare biodegradable films.

The food industry is an example of the development of biopolymers, either as coatings or edible films. Their application has generated significant changes, improving the quality of almost any food system since films serve as barriers to mass transfer of moisture, oxygen, carbon dioxide, lipids, flavor, and aroma between food components and the surrounding atmosphere (McHugh, 2000). Biopolymer-based packaging prolongs the shelf life of several foods (Toğrul \& Arslan, 2003), reduces weight loss and the deterioration of sensory characteristics (Chien et al., 2007), inhibits the growth of microorganisms (Durango et al., 2005), and reduces the impact on the environment by decreasing packaging disposal.

Chitosan is a polysaccharide found naturally in the cell walls of some crustaceans, plants, and fungi. It is produced by complete deacetylation of chitin in acid conditions. It is a non-toxic, biocompatible, and biodegradable natural product. Several researchers have found that it has strong antimicrobial and antifungal activity (Darmadji \& Izumimoto, 1994; Jo et al., 2001). In the production of chitosan, chitin plays a very important role because the degree of deacetylation and molecular weight depends on the source (crustaceans, insects, molluscs and fungi) (Expósito, 2010).

Gelatin is a protein derived from the partial hydrolysis of collagen. Like most proteins, gelatin-based films generally have good barrier properties against oxygen, and relatively good tensile properties, but water vapor permeability (WVP) is poor due to the hydrophilic nature of gelatin (Gennadios \& Weller, 1990; Arvanitoyannis et al., 1998; Patil et al., 2000; Bigi et al., 2002, Avena-Bustillos et al., 2006). Recent studies have found that the physicochemical properties of gelatin film can be improved by adding other constituents, such as chitosan and transglutaminase; compounds that modify its structural composition (Tharanathan, 2003). 
Transglutaminase is a transferase that promotes protein polymerization. It is also considered as a potential agent for increasing the functionality and interaction of proteins in food (Ramírez-Suárez \& Xiong, 2003). Transglutaminase catalyzes the acyl-transferase reaction between $\gamma$-carboxyamide groups of glutamine residues and the $\mathfrak{E}$-amino group of lysine residues (acyl). Its action results in the formation of $l$-( $\gamma$-glutaminyl) and intermolecular lysine in cross-linked proteins (DeJong \& Koppelman, 2002). The effect of transglutaminase on the properties of films have been studied in several proteins: milk (Oh et al., 2004), 11 S globulin (Yildirim \& Hettiarachchy, 1998), egg white (Lim et al., 1999), soybean meal (Mariniello et al., 2003) and gelatin (Thomazine et al., 2005). In the past, the limited availability and high cost of transglutaminase restricted its use. Today, microbial transglutaminase (MTgase) is significantly more economical and makes its use feasible as a cross-linking agent in films. Composite films based on chitosan and fish gelatin could have better properties compared to those films made entirely from chitosan or gelatin.

In food packaging, water molecules adsorbed by hydrophilic films especially at high relative humidity conditions could promote changes in the internal structure modifying the mechanical and barrier properties. Changes in the functional properties of the film might have an important effect on its performance during storage or transporting, resulting in important changes in the protection of food products. The aim of this study was to evaluate the effect of relative humidity on tensile and water vapor properties of films made from chitosan and gelatin.

\section{Materials and methods}

\subsection{Materials}

Commercial fish gelatin, provided by Nitta Gelatin, Inc. (G7765) (Morrisville, NC), and commercial chitosan (Chitosan medium molecular weight 448877-2506, 75-80\% deacetylation degree, Sigma-Aldrich, St Louis, MO), were used for the preparation of biopolymer films. Distilled water or acetic acid 99\% (Sigma-Aldrich) was used as a solvent for gelatin or chitosan, respectively. Glycerol 99\% pure (Sigma-Aldrich) was added as plasticizer and Activa TI microbial transglutaminase (Ajinomoto Food Ingredients Co.) was used as a binding agent.

\subsection{Development and conditioning of films}

Chitosan 1\% (w/v) and gelatin 6\% (w/v) solutions were prepared. Chitosan was dissolved in acetic acid 2\% (v/v) and gelatin was hydrated in distilled water. Both solutions were maintained at $55^{\circ} \mathrm{C}$. Prior to preparation of the mixtures, MTGase was dissolved in distilled water at $55^{\circ} \mathrm{C}$. Corresponding mixtures were prepared in the following proportions: 100:0, 75:25, 50:50 (v/v) chitosan:gelatin with the addition of glycerol $(0.1 \mathrm{~mL} / \mathrm{g}$ of gelatin) and $1 \%$ MTGase. The solutions were poured into acrylic plates and maintained at room temperature for $30 \mathrm{~h}$ for drying.

Film samples were conditioned at different relative humidity following the static microclimate method reported by Wolf et al. (1985) with some modifications. Supersaturated salt solutions were prepared by dissolving $\mathrm{LiCl} . \mathrm{H}_{2} \mathrm{O}, \mathrm{MgCl}_{2} \cdot 6 \mathrm{H}_{2} \mathrm{O}, \mathrm{K}_{2} \mathrm{CO}_{3} .2 \mathrm{H}_{2} \mathrm{O}$,
$\mathrm{NaBr}, \mathrm{NaCl}$ and $\mathrm{KCl}$ in distilled water to obtain microclimates of $11.1,22.6,32.7,43.8,57.7,75.3$ and $84.3 \%$ relative humidity environments at $30^{\circ} \mathrm{C}$, respectively

One-L acrylic containers with airtight lid were used to condition the film samples during 7 days before testing. For equilibrium moisture content of the films, once conditioned, dry weight was determined in an oven at $110^{\circ} \mathrm{C}$ for $12 \mathrm{~h}$ and the moisture content at equilibrium was determined by weight difference and expressed as a percentage.

Color of the films was determined using a MiniScan XE Plus spectrocolorimeter (HunterLab, model 45/0-L; Hunter Associates, Reston, VA). The parameters defined by the Commission Internationale de L'Eclairage (CIE) $\mathrm{L}^{*}, \mathrm{a}^{*}$ and $\mathrm{b}^{*}$ values, chrome $\left(C, \operatorname{sqrt}\left(a^{\star} 2+b^{\star} 2\right)\right)$ and hue angle $\left(H, \operatorname{arc} \tan b^{\star} / a^{\star}\right)$ were calculated based on illuminant $\mathrm{C}$ and the $2^{\circ}$ standard observer.

\subsection{Mechanical properties}

Tensile strength and elongation were determined according to the ASTM D882-00 (American Society for Testing and Materials, 2001a) standard test method using a texture analyzer (TA Plus, Lloyd Instruments, Largo, FL) equipped with mechanical grips with an initial separation of $50 \mathrm{~mm}$, operating at a crosshead speed of $1 \mathrm{~mm} / \mathrm{s}$. For the test, films were cut into $1 \times 9 \mathrm{~cm}$ samples and twenty replicates were measured and only those samples that ruptured in the center were considered for data analysis; thus, the mean and standard deviation of at least 10 samples were obtained. Film thickness was determined using a digital micrometer (Mitutoyo Corp., Tokyo, Japan).

\subsection{Water vapor permeability (WVP)}

WVP was determined using the standard test method for water vapor transmission of materials ASTM E96-00 (American Society for Testing and Materials, 2001b) with some modifications. Films were cut into circles and placed between two silicon $\mathrm{O}$-rings on the top of a $3.4 \mathrm{~cm}$ inner diameter glass permeability cell, $4.0 \mathrm{~cm}$ deep, with an exposure area of $0.000907 \mathrm{~m}^{2}$, containing $10 \mathrm{~mL}$ of distilled water to achieve a relative humidity close to saturation. The cell was placed inside of a temperature controlled $\left(30 \pm 0.5^{\circ} \mathrm{C}\right)$ chamber containing silica gel to maintain a dry environment. The weight variation of the permeability cell containing the film was recorded automatically every $30 \mathrm{~min}$ for $6 \mathrm{~h}$ using an analytical balance to record weight loss versus time. The water vapor transmission rate (WVTR) was calculated from the slope of the weight loss curve divided by the area of film exposure $\left(0.000907 \mathrm{~m}^{2}\right)$. WVP was calculated with Equation 1 (Romero, 1994) where $\Delta \mathrm{P}$ is the difference in water vapor pressure on both sides of the film, which in the experimental setup used in this study is equal to $4237.45 \mathrm{~Pa}$ and $\mathrm{E}$ is film thickness. Three replicates per treatment were performed.

$$
P V A=\frac{V T V A}{\Delta P}[E]
$$

\subsection{Statistical analysis}

To describe the effect of fish gelatin concentration and relative humidity on chitosan films, a second-order polynomial model was applied to the experimental data. To assess the quality 
of the fit, $\mathrm{R}^{2}$ and adjusted $\mathrm{R}^{2}$ were used along with the critical F-value to determine if the model was adequate for describing the experimental data.

\section{Results and discussion}

Films with different chitosan-gelatin ratios (100:0, 75:25, 50:50) and MTGase were homogeneous, flexible, and with appropriate manageability. The recorded thickness ranged from 0.0375 to $0.0909 \mathrm{~mm}$, based on the proportion of gelatin in the mixtures. As for color, according to the Hunter scale, the films were transparent, yellowish gray with no significant variations as a function of the chitosan-gelatin ratios.

The equilibrium moisture content of chitosan films as a function of gelatin and relative humidity is shown in Figure 1. The parameters calculated for the polynomial equation describing the absorbed moisture in the biopolymeric film are shown in Table 1. The critical F and $\mathrm{R}^{2}$ values indicate a proper fit of the model to the experimental data. In general, films absorbed more water as relative humidity increased; a typical behavior of hydrophilic material. However, the results show that the addition of gelatin reduced the ability of chitosan films to absorb water from a value close to $110 \%$ to about $34 \%$ when films were conditioned at $\mathrm{RH}$ values of $84 \%$. Although gelatin is water soluble, the results suggest that the interaction of chitosan with protein when films are formed, limits the number of sites for water binding, which reduces its water absorption capacity.

\subsection{Mechanical properties}

Tensile strength

The results of tensile strength in chitosan films with MTgase as a function of fish gelatin concentration and relative humidity are shown in Figure 2. The parameters used in the mathematical model to describe tensile strength are shown in Table 1. The critical $\mathrm{F}$ and $\mathrm{R}^{2}$ values obtained indicate a proper fit to the experimental data. As shown, an increase in gelatin concentration resulted in a reduction in tensile strength especially at higher values of relative humidity. It has been reported that even when films prepared from gelatin have good mechanical properties, hydrophilic behavior is poor (Arvanitoyannis et al., 1998; Avena-Bustillos et al., 2006). Chitosan enhances film structure as tensile strength increased when the concentration of chitosan

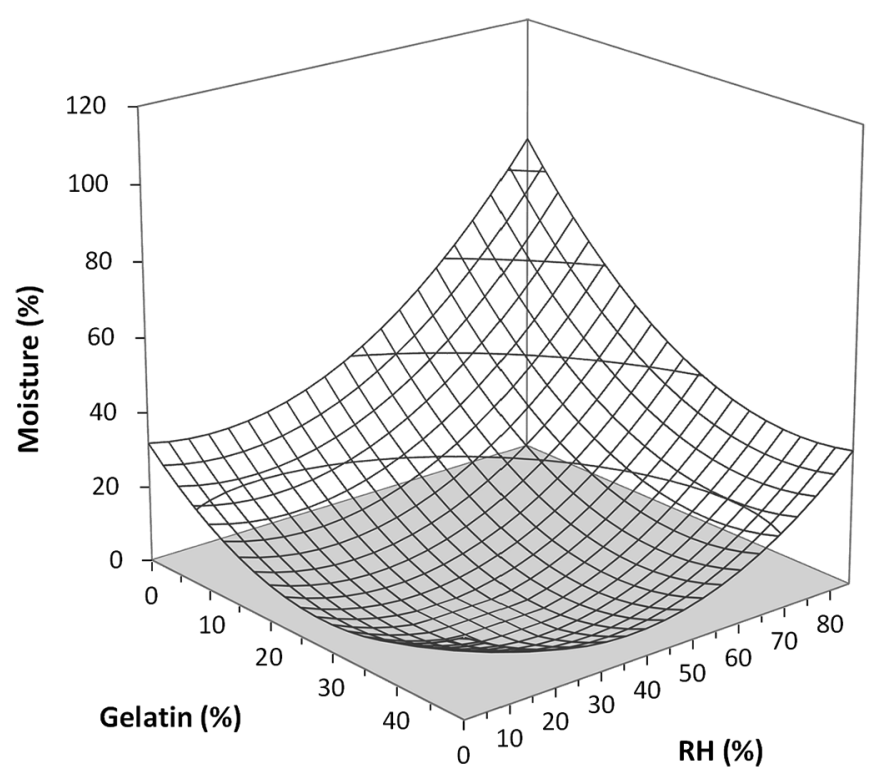

Figure 1. Moisture content of chitosan films with $1 \%$ MTgase as a function of gelatin concentrations and relative humidity.

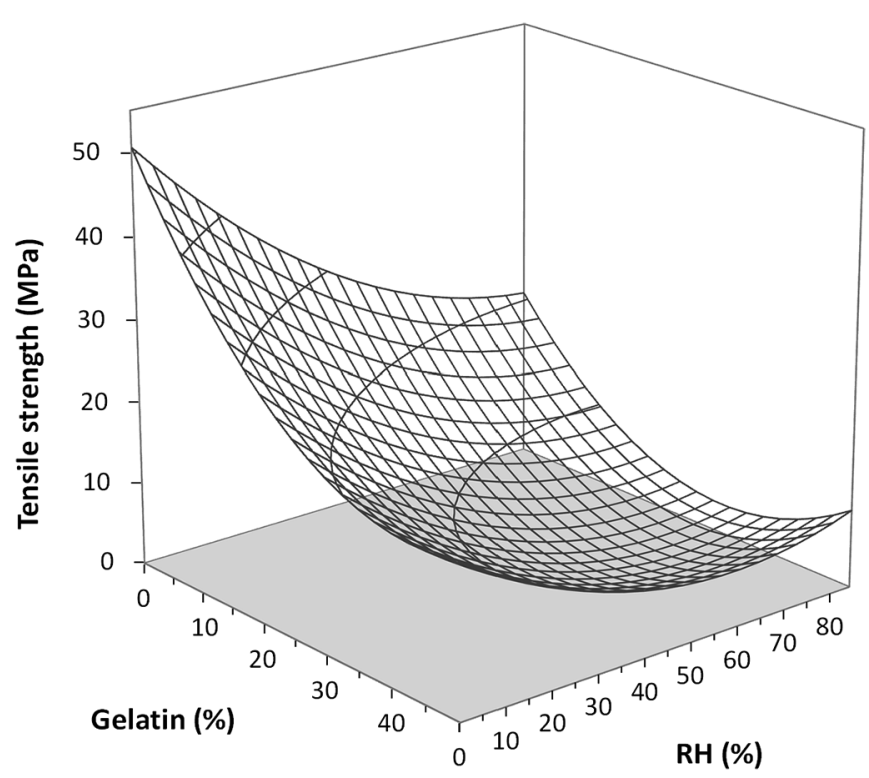

Figure 2. MPa tensile strength of chitosan films with 1\% MTgase as a function of gelatin concentrations and relative humidity.

Table 1. Parameters calculated for the multiple linear regression model.

\begin{tabular}{|c|c|c|c|c|}
\hline Model & $\begin{array}{c}\text { Moisture } \\
(\%)\end{array}$ & $\begin{array}{l}\text { Tensile strength } \\
(\mathrm{MPa})\end{array}$ & $\begin{array}{c}\text { Elongation } \\
(\%)\end{array}$ & $\begin{array}{c}\text { WVP } \\
(\mathrm{g} / \mathrm{m} \mathrm{s} \mathrm{Pa})\end{array}$ \\
\hline Interception & 31.79185 & 50.67179 & 15.08694 & $4.1175 \mathrm{E}-11$ \\
\hline $\mathrm{RH}$ & -0.32388 & -0.66416 & -0.36669 & $-1.22411 \mathrm{E}-12$ \\
\hline Gelatin & -1.71725 & -1.49613 & -1.44448 & $-1.49564 \mathrm{E}-12$ \\
\hline $\mathrm{RH}^{\star}$ Gelatin & -0.00968 & 0.00497 & 0.01262 & $2.17568 \mathrm{E}-14$ \\
\hline $\mathrm{RH}^{2}$ & 0.01173 & 0.00365 & 0.00617 & $2.65487 \mathrm{E}-14$ \\
\hline Gelatin $^{2}$ & 0.02998 & 0.01712 & 0.02180 & $2.95623 \mathrm{E}-14$ \\
\hline $\mathrm{R}^{2}$ & 0.93947 & 0.83340 & 0.82759 & 0.85631 \\
\hline $\mathrm{R}^{2}$ adjusted & 0.91425 & 0.76398 & 0.75575 & 0.79644 \\
\hline Critical F & $6.65583 \mathrm{E}-07$ & 0.00025 & 0.00030 & 0.00011 \\
\hline
\end{tabular}

$\mathrm{RH}$, relative humidity. WVP, water vapor permeability. 
increased registering a maximum of $43 \mathrm{MPa}$ for films without gelatin. In studies of the rheological, mechanical and barrier properties of gelatin and chitosan composite films, the addition of chitosan did not change the mechanical properties of gelatin films; also, the addition of glycerol caused a significant increase in deformation and a decrease in the resistance of the composite, regardless of the protein concentration used (Gontard et al.,1993; Rivero et al., 2005). However, another study reported that the degree of deacetylation affects the physical, chemical, and biological properties of chitosan, such as tensile strength, the ability to chelate ions, and immunological activity (Valenzuela, 2006). Regarding the presence of MTgase, Babin \& Dickinson (2001) reported that the effect of the enzyme may be positive or negative on the gelatin's strength, depending on the order in which crosslinks are formed. Also, Carvalho \& Grosso (2004) demostrated that adding transglutaminase did not produce any change in mechanical strength concluding that MTgase has little effect on increasing tensile strength compared with other chemical cross-linking agents used.

\section{Elongation}

The percentage of elongation of chitosan films with MTGase as a function of fish gelatin concentration and relative humidity is shown in Figure 3. The mathematical model parameters used to describe the percentage of elongation are shown in Table 1. The critical $F$ and $R^{2}$ values found show that the model adequately fits the experimental data. In general, the films showed an increase in deformation with respect to percent of relative humidity and gelatin concentration. The 50:50 chitosan-gelatin films showed $65 \%$ deformity with the maximum relative humidity tested. Fish gelatin mixed with other compounds has shown a suitable plasticizing effect (Bigi et al., 2002). Furthermore, these results showed that relative humidity affected the films containing only chitosan as the deformation ranged from 18 to $28 \%$ at the relative humidities studied. This behavior may be due to the inclusion of glycerol as a plasticizer since it interferes with cross-links resulting in increased film elongation, thus improving flexibility (Rojas-Graü et al., 2007; Raybaudi-Massilia et al., 2008).

\subsection{Water vapor permeability}

Water vapor permeability of chitosan films with MTgase and fish gelatin (Figure 4) increases with respect to relative humidity and gelatin concentration. Parameters contained in the mathematical model that describe water vapor permeability are shown in Table 1 . The critical $\mathrm{F}$ and $\mathrm{R}^{2}$ values indicate a proper fit of the model to the experimental data. These results are similar to other studies where chitosan and fish gelatin-based films were prepared, such as those obtained by Rivero et al. (2005) whose WVP values were: $6.34 \times 10^{-11} \mathrm{gm}^{-1} \mathrm{~s}^{-1} \mathrm{~Pa}^{-1}$ for $100 \%$ chitosan samples and $3.0 \times 10^{-10} \mathrm{gm}^{-1} \mathrm{~s}^{-1} \mathrm{~Pa}^{-1}$ for $100 \%$ gelatin samples; showing intermediate values in composite films, indicating that chitosan plus glycerol give better barrier properties. Gelatin-based films generally have a good oxygen barrier and relatively good mechanical properties, but low water vapor permeability (Arvanitoyannis et al., 1998; Avena-Bustillos et al., 2006). Regarding the presence of the enzyme, Soler (2010) indicates that the use of MTgase has been widely reported in the development of gelatin

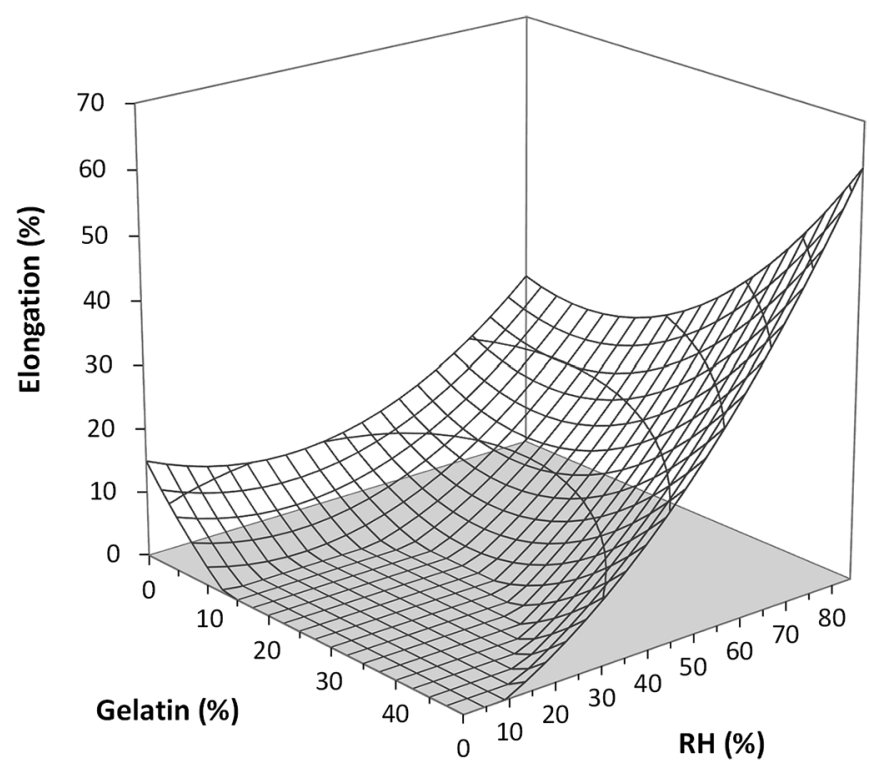

Figure 3. Percent elongation of chitosan films with $1 \%$ MTgase as a function of gelatin concentrations and relative humidity.

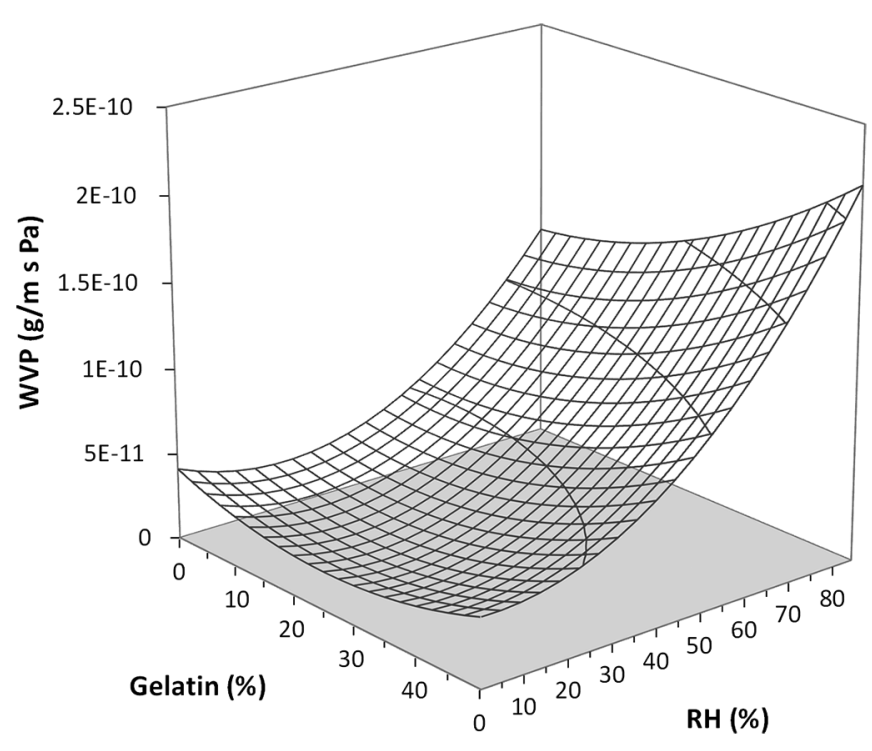

Figure 4. Water vapor permeability of chitosan films with $1 \%$ MTgase as a function of gelatin concentrations and relative humidity.

films as a crosslink agent between proteins, affecting certain properties. On the other hand, the addition of a hydrophilic component as plasticizer favors adsorption and desorption of water molecules, increasing the permeability of films obtained from hydrocolloids. Studies of sorbitol added as a plasticizer have shown that permeability to water vapor may increase because of its hydrophilicity, and mask the effect of cross-linking induced by MTgase (Kim, 2005; Tang et al., 2005).

\section{Conclusions}

Films made from chitosan, glycerol, MTgase and fish gelatin, showed adequate properties and physical appearance as a packaging material. The most adequate proportion of the mixtures studied was 75:25, chitosan:fish gelatin. The increase 
in relative humidity caused a decrease in tensile strength and an increase in deformation and water vapor permeability. Despite the disadvantages related to the properties of gelatin in edible films, chitosan and MTgase remain good alternatives to improve the structural composition of these films. The mixture of chitosan from different sources and the degree of deacetylation with proteins in different concentrations is still a subject of investigation.

\section{References}

Allsopp, M., Walters, A., Santillo, D., \& Johnston, P. (2007). Contaminación por plástico en los océanos del mundo. España: Greenpeace. Retrieved from http://www.bio-nica.info/Biblioteca/ Allsopp2007Contaminacion.pdf

American Society for Testing and Materials - ASTM. (2001a). D88200: standard test methods for tensile properties of thin plastic sheeting (Annual Book of ASTM Standards). Philadelphia: ASTM.

American Society for Testing and Materials - ASTM. (2001b). E96-00: standard methods of test for water vapor transmission of materials in sheet form (Annual Book of ASTM Standards). Philadelphia: ASTM.

Arvanitoyannis, I. S., Nakayama, A., \& Aiba, S. (1998). Chitosan and gelatin based edible films: state diagrams, mechanical and permeation properties. Carbohydrate Polymers, 37(4), 371-382. http://dx.doi. org/10.1016/S0144-8617(98)00083-6.

Avena-Bustillos, R. J., Olsen, C. W., Olson, D. A., Chiou, B., Yee, E., Bechtel, P. J., \& McHugh, T. H. (2006). Water vapor permeability of mammalian and fish gelatin film. Journal of Food Science, 71(4), 202-207.

Ávila, R. M. (2011). Efecto de la adición de zaina sobre las propiedades mecánicas y de barrera de películas de gelatina de pescado con transglutaminase (Doctoral thesis). Universidad Autónoma de Tamaulipas, México.

Babin, H., \& Dickinson, E. (2001). Influence of transglutaminase treatment on the thermoreversible gelation of gelatin. Food Hydrocolloids, 15(3), 271-276. http://dx.doi.org/10.1016/S0268-005X(01)00025-X.

Bigi, A., Cojazzi, G., Panzavolta, S., Roveri, N., \& Rubini, K. (2002). Stabilization of gelatin films by cosslinking with genipin. Biomaterials, 23(24), 4827-4832. http://dx.doi.org/10.1016/S0142-9612(02)002351. PMid:12361622.

Carvalho, R. A., \& Grosso, C. R. F. (2004). Characterization of gelatin based films modified with trasglutaminase, glyoxal and formaldehyde. Food Hydrocolloids, 18(5), 717-726. http://dx.doi.org/10.1016/j. foodhyd.2003.10.005.

Chien, P. J., Sheu, F., \& Yang, F. H. (2007). Effects of edible chitosan coating on quality and shelf life of sliced mango fruit. Journal of Food Engineering, 78(1), 225-229. http://dx.doi.org/10.1016/j. jfoodeng.2005.09.022.

Darmadji, P., \& Izumimoto, M. (1994). Effect of chitosan in meat preservation. Meat Science, 38(2), 243-254.

DeJong, G. A. H., \& Koppelman, S. J. (2002). Transglutaminase catalyzed reactions: impact on food applications. Journal of Food Science, 67(8), 2798-2806. http://dx.doi.org/10.1111/j.1365-2621.2002.tb08819.x.

Durango, A. M., Soares, N. F. F., \& Andrade, N. J. (2005). Microbiological evaluation of an edible antimicrobial coating on minimally processed carrots. Food Control, 17(5), 336-341. http://dx.doi.org/10.1016/j. foodcont.2004.10.024.

Expósito, H. R. (2010). Quitosano: un biopolímero con aplicaciones en sistemas de liberación controlada de fármacos (Doctoral thesis). Universidad Complutense de Madrid, Madrid.
Gennadios, A., \& Weller, C. L. (1990). Edible films and coating from wheat and corn proteins. Food Technology, 44(10), 63-69.

Gontard, N., Guilbert, S., \& Cuq, J. (1993). Water and glycerol as plasticizers affect mechanical and water vapor barrier properties of an edible wheat gluten film. Journal of Food Science, 58(1), 206-211. http://dx.doi.org/10.1111/j.1365-2621.1993.tb03246.x.

Han, C., Zhao, Y., Leonard, S. W., \& Traber, M. G. (2004). Edible coatings to improve storability and enhance nutritional value of fresh and frozen strawberries (Fragaria ananassa) and raspberries (Rubus ideaus). Postharvest Biology and Technology, 33(1), 67-78. http://dx.doi.org/10.1016/j.postharvbio.2004.01.008.

Jo, C., Lee, J. W., Lee, K. H., \& Byun, M. W. (2001). Quality properties of pork sausage prepared with water-soluble chitosan oligomer. Meat Science, 59(4), 369-375. http://dx.doi.org/10.1016/S03091740(01)00089-4. PMid:22062961.

Kim, Y. T. (2005). Development and characterization of gelatin film as active packaging layer. Clemson: Clemson University.

Krochta, J., Baldwin, E., \& Nisperos-Carriedo, M. (1994). Edible coatings and films to improve food quality. New York: Editorial Technomic Publishing Company.

Lacroix, M. (2009). Mechanical and permeability properties of edible films and coatings for food and pharmaceutical applications. In M. E. Embuscado \& K. C. Huber (Eds.), Edible films and coatings for food applications. New York: Springer. http://dx.doi.org/10.1007/9780-387-92824-1_13.

Lim, L. T., Mine, Y., \& Tung, M. A. (1999). Barrier and tensile properties of transglutaminase cross-linked gelatin films as affected by relative humidity, temperature, and glycerol content. Journal of Food Science, 64(4), 616-622. http://dx.doi.org/10.1111/j.1365-2621.1999.tb15096.x.

Mariniello, L., Di Pierro, P., Esposito, C., Sorrentino, A., Masi, P., \& Porta, R. (2003). Preparation and mechanical properties of edible pectin-soy flour films obtained in the absence or presence of transglutaminasa. Journal of Biotechnology, 102(2), 191-198. http://dx.doi.org/10.1016/ S0168-1656(03)00025-7. PMid:12697396.

McHugh, T. H. (2000). Protein-lipid interactions in edible films and coatings. Die Nahrung, 44(3), 148-151. http://dx.doi.org/10.1002/15213803(20000501)44:3<148::AID-FOOD148>3.0.CO;2-P. PMid:10907233.

Oh, J. H., Wang, B., Field, P. D., \& Aglan, H. A. (2004). Characteristics of edible films made from dairy proteins and zein hydrolysate crosslinked whith transglutaminasa. International Journal of Food Science \& Technology, 39(3), 287-294. http://dx.doi.org/10.1111/j.13652621.2004.00783.x.

Patil, R. D., Dalev, P. G., Mark, J. E., Vassileva, E., \& Fakirov, S. (2000). Biodegradation of chemically modified gelatin films in lake and river waters. Journal of Applied Polymer Science, 76(1), 29-37. http:// dx.doi.org/10.1002/(SICI)1097-4628(20000404)76:1<29::AIDAPP4>3.0.CO;2-I.

Rabell-Contreras, M. F., Vázquez-Morillas, A., Espinosa-Valdemar, R. M., Beltrán-Villavicencio, M., Osada-Velázquez, M. H., \& González-Filio, J. U. (2011). Estudio de factibilidad de biodegradación de plásticos mediante composteo. In Anales del IV Simposio Iberoamericano de Ingeniería de Residuos, México.

Ramírez-Suárez, J. C., \& Xiong, Y. L. (2003). Effect of transglutaminase induced cross-linking on gelation of myofibrillar/soy protein mixtures. Meat Science, 65(2), 899-907. http://dx.doi.org/10.1016/ S0309-1740(02)00297-8. PMid:22063454.

Raybaudi-Massilia, R. M., Rojas-Graû, M. A., Mosqueda-Melgar, J., \& Martin-Belloso, O. (2008). Comparative study on essential oils incorporated into an alginate-based edible coating to assure the 
safety and quality of fresh-cut Fuji apples. Journal of Food Protection, 71(6), 1150-1161. PMid:18592740.

Rivero, S., García, M. A., \& Pinotti, A. (2005). Propiedades reológicas, de barrera y mecánicas de películas compuestas de gelatina y quitosano. In Congreso Latinoamericano de Ingeniería y Ciencias Aplicadas, Mendoza.

Rojas-Graû, M. A., Grasa-Guillem, R., \& Martin-Blloso, O. (2007). Quality changes in fresh-cut Fuji apple as affected by ripeness stage, antibrowning agents, and storage atmosphere. Journal of Food Science, 72(1), 36-43.

Romero, C. A. (1994). Desarrollo y evaluación de una película biodegradable a base de zeina y etilcelulosa. Efectos de la hidratación sobre la eficiencia de la misma (Master's dissertation). Universidad Autónoma de Querétaro, México.

Soler, M. A. D. (2010). Efecto de la temperatura de secado y de la transglutaminasa en las propiedades mecánicas y permeabilidad al vapor de agua de películas de gelatina de pescado (Doctoral thesis). Universidad Autónoma de Tamaulipas, México.

Stevens, E. S. (2002). Green plastics: an introduction to the new science of biodegradable plastics. Princeton: Princeton University Press.

Tang, C. H., Jiang, Y., Wen, Q.-B., \& Yang, X.-Q. (2005). Effect of transglutaminase treatment on the properties of cast films of soy protein isolates. Journal of Biotechnology, 120(3), 296-307. http:// dx.doi.org/10.1016/j.jbiotec.2005.06.020. PMid:16084619.
Tharanathan, R. N. (2003). Biodegradable films and composite coatings: past, present and future. Trends in Food Science \& Technology, 14(3), 71-78. http://dx.doi.org/10.1016/S0924-2244(02)00280-7.

Thomazine, M., Carvalho, R., \& Sobral, P. (2005). Physical properties of gelatin films plasticized by blends of glycerol and sorbitol. Journal of Food Science, 70(3), 172-176. http://dx.doi.org/10.1111/j.1365-2621.2005. tb07132.x.

Toğrul, H., \& Arslan, N. (2003). Extending shelf-life of peach and pear by using CMC from sugar beet pulp cellulose as hydrophilic polymer emulsions. Food Hydrocolloids, 18(2), 215-226. http:// dx.doi.org/10.1016/S0268-005X(03)00066-3.

Valenzuela, C. (2006). Obtención de quitosano de pota (Dosificas gigas) empleando altas dosis de radiación gamma (Bachelor thesis). Universidad Nacional Mayor de San Marcos, Perú.

Villada, S. H., Acosta, A. H., \& Velazco, J. R. (2007). Biopolímeros naturales usados en empaques biodegradables. Temas Agrarios, 12(2), 5-13.

Wolf, W., Spiess, W. E. L., \& Jung, G. (1985). Standardization of isotherm measurements (cost-project 90 and 90 bis). In D. Simatos \& J. L. Multon (Eds.), Properties of water in foods (661 p.). Dordrecht: Martinum Nijhoff. http://dx.doi.org/10.1007/978-94-009-5103-7_40.

Yildirim, M., \& Hettiarachchy, N. S. (1998). Properties of films produced by cross-linking whey proteins and 11S globulin using transglutaminasa. Journal of Food Science, 63(2), 248-252. http:// dx.doi.org/10.1111/j.1365-2621.1998.tb15719.x. 